\title{
GIS in the History Classroom: Displaying the Walls of Elvas and Badajoz through the Use of Google Earth ${ }^{\dagger}$
}

\author{
Mario Corrales-Serrano ${ }^{1, *}$, Jesús Sánchez-Martín ${ }^{2}$, José Moreno-Losada ${ }^{1}$ and \\ Francisco Zamora-Polo ${ }^{3}$ \\ 1 Departamento de Didáctica de las Ciencias Sociales, Lengua y Literatura, Facultad de Educación, \\ Universidad de Extremadura, 06006 Badajoz, Spain; jmorenol@unex.es \\ 2 Departamento de Didáctica de las Ciencias Experimentales y Matemáticas, Facultad de Educación, \\ Universidad de Extremadura, 06006 Badajoz, Spain; jsanmar@unex.es \\ 3 Departamento de Ingeniería del Diseño, Escuela Politécnica Superior, Universidad de Sevilla, \\ 41011 Sevilla, Spain; fzpolo@us.es \\ * Correspondence: mariocorralesserrano@gmail.com; Tel.: +34-674964987 \\ + Presented at the 5th Ibero-American Congress on Entrepreneurship, Energy, Environment and \\ Technology-CIEEMAT, Portalegre, Portugal, 11-13 September 2019.
}

Published: 25 December 2019

\begin{abstract}
The study of History in Secondary Education often develops in an excessively theoretical way, without the students having the chance to apply the acquired abilities practically. However, educational studies prove that all abilities are more adequately acquired when the teaching and learning process combines theoretical and practical developments. The current research work combines interest for the historical heritage of cities as a useful element for the development of historical educational abilities with the use of technologies related to Geography, such as Geographic Information Systems (GIS), relating to a key heritage element: the wall. The main objective is to teach what a wall is and what its function is in a medieval city, as well as ins in current cities. A combination of methodologies has been carried out to achieve this objective, those are applied in a theoretical phase, a practical phase and a technological one. The learning outcomes are satisfactory, given that a greater amount of ability acquisition is detected related to a traditional theory class.
\end{abstract}

Keywords: social sciences teaching; usefulness; motivation; practice; GIS

\section{Introduction}

The historical heritage of cities is, without a doubt, one of the most expressive elements among those that connect the past of a specific place with its present. The use of historical heritage as a tool for the implementation of innovative strategies in the teaching and learning process is a very widespread trend in the current teaching of Social Sciences. Recent studies underline the importance of using the city's own heritage as an aiding tool for the understanding of historical phenomenon and events in the teaching of History in Secondary Education. There are many studies that support this use of heritage as an educational tool, which cannot be replaced by any other element [1-3].

Given the importance of heritage in Social Science teaching, it can be confirmed how this element has a notable influence on the contents of the textbooks for the subject of History, [4,5] highlight some difficulties in learning about historical heritage through these textbooks:

“... a lack of interest from the educational administration can be observed, from the authors of textbooks, teachers and heritage managers in conceptualising heritage as educational content or any 
updating their educational communication and learning in the classroom from the most recent contributions to the research" [5] (p.575).

Given the importance of heritage in the teaching of social sciences, it can be seen how this element has a relevant impact on the contents of the textbooks of the subject of History. These studies refer to some difficulties in learning about historical heritage through these textbooks:

"there is little interest on the part of the educational administration, textbook authors, teachers and heritage managers in conceptualizing heritage as school content or in updating their didactic communication and classroom learning based on the most recent research contributions" [5] (p. 575).

These difficulties refer as much to the conceptualisation of historical heritage as the educational work with analysis templates, which allow it to be incorporated into the teaching-learning process of History.

This work presents a combination of the educational use of heritage with the use of technology normally applied in the field of Geography: Geographic Information Systems (GIS). The emergence of ICT in the development of teaching activity has had, and continues to have, a great importance in the field of teaching geography and it is being made possible to carry out the development of new strategies of getting closer to the subject's own content, with specific tools, GIS, which have gained a lot of importance in the teaching of geography in recent years [6]. From our point of view, the implementation of new learning methods, such as the use of ICT and GIS [7] is suitable for the teaching and learning of Social Sciences to the extent that they contribute to solving problems and difficulties that can arise in the development of subjects. In addition, the combination of the use of this heritage with the use of technology increases, without a doubt, the motivation in interest for learning by the students.

\section{Experience of the Educational Use of Heritage and GIS}

The experiment carried out consists of getting closer to the study of History in cities, just as is set out in the Secondary Education curriculum, based in one of its basic structures: the wall. Two bordering cities, which are linked through the Eurociudad agreement, one Spanish and one Portuguese, Elvas and Badajoz, are defined in their historical urban structure by the wall, which serves as a mark of the passage of time in the city.

\subsection{Objectives}

The educational objectives that go along with this investigation are the following:

- To teach what a wall is and what its function is in the cities during the Middle Ages and the following years.

- To make the urban organisation process of their city in different periods and at present visible to the students through an element of heritage such as the wall.

- To show the possibilities that geolocation tools offer for the learning of abilities related to History.

- To increase the motivation and interest of students for the study of history.

All these objectives are related to the need to implement educational strategies that make the practical development of abilities and contents possible in the Social Sciences classroom [8], in such a way that the usefulness of learning the said abilities is shown [9].

\subsection{Sample}

The experiment has been done with a sample of 63 s year ESO (compulsory secondary education) students, in the subjects Geography and History, who belong to two different groups (32 and 31 students respectively). The most important characteristics of this group of students are the following:

- The distribution of the sample by gender is $44 \%$ boys and $56 \%$ girls. 
- If the qualifications of the students in the sample of Geography and History are taken into account, the distribution is the following: $25 \% \mathrm{~A}, 33 \% \mathrm{~B}, 24 \% \mathrm{C}$, and $18 \%$ failed the first round of exams.

- Regarding how much they like the subject, the students in the sample rated their interest in Geography and History between 5 and 6 out of 10 .

- Among both groups there are 4 students with special educational needs, which have been integrated into the development of the experience.

- For some of the activities of this experience, the students from the sample have been distributed into groups of 5 .

\subsection{Abilities that Have been Worked on}

As explained in the introduction, the abilities that have been worked on in this educational experience are related to the role of the wall in the city, starting from the medieval era, and applying it to the two specific cases of the present time: the walls of Elvas and Badajoz. These two specific cases have been chosen due to the fact they form part of the context of the students in the sample, who live in the city of Badajoz and have Elvas only $21 \mathrm{~km}$ away.

Regarding the contents and abilities in the Geography and History curriculum for second-year ESO (compulsory secondary education) students that are related to the knowledge of cities and their urban heritage structures, Table 1 shows a selection of these contents.

Table 1. Curriculum contents developed in the educational experience. Source: decree 98/2016.

\begin{tabular}{ccc}
\hline \multicolumn{3}{c}{ Curriculum Contents } \\
\hline Contents & Evaluation Criteria & Assessable Standards \\
\hline Medieval cities. Recovery, & To understand the medieval & Explain the revival of the cities \\
functions and spaces. & urban renaissance and to know & and its characteristics: \\
The urban renaissance. & the medieval city and its living & Trade unions, cathedrals, \\
The hamlet. & conditions. & universities, walls, etc. \\
\hline
\end{tabular}

\subsection{Methodology}

The implemented educational strategy has been carried out in three phases:

- Theoretical phase: in this phase, the students have learnt the theoretical contents around the city and the fusion of the wall into the city. In order to carry out this phase, a combination of demonstrative traditional methodologies and a Flipped Classroom [10] methodology were employed, using an educational video with which the students could reinforce the displayed contents. The activity for this phase consisted of doing a digital questionnaire to show the amount of content acquisition carried out.

- Practical phase: this phase consisted of the visit to the walls in these cities. The visit was designed to identify the theoretical contents studied in the previous phase. As explained in the introduction, direct contact with the monumental heritage of the cities greatly favours the acquisition of learning standards for the subjects Geography and History, as much as the motivation of students with regards to learning said contents [2,3]. This phase's activity consisted of writing a 100-word commentary about the visit to the walls. In this commentary these questions must be answered: Have you been able to identify the characteristics of the wall you have studied? What do you understand about the relation between the wall and the city after this visit?

- Technological phase: in this phase, the students have been given use of GIS tools, such as the geolocation system Google Earth, in order to view the city and the wall from a new perspective, and this completed the learning phase. This display was done in groups of 5 students, therefore favouring cooperative learning [11] and allowing the students to interact with the possibilities that the Google Earth application offers. Figure 1a,b) shows two screenshots of the view of both walls through Google Earth. 


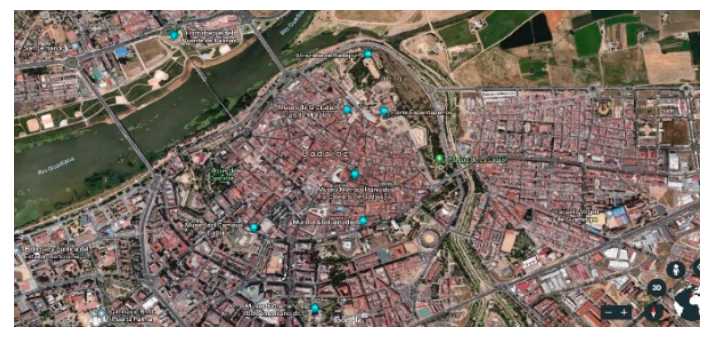

(a)

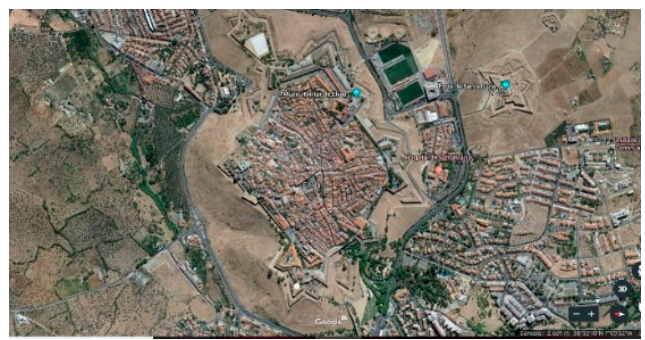

(b)

Figure 1. View through Google Earth. (a) View of the Badajoz wall through Google Earth. (b) View of the Elvas wall through Google Earth.

This phase's activity consisted of locating the Elvas and Badajoz walls through the application and discussing what the walls themselves look like and how they are related to the rest of the city. For this, the students once again wrote a 100-word commentary, responding to the same questions as in the previous part. Finally, they were asked to discuss the experience in general, combining the three phases.

\section{Results and Discussion}

In order to evaluate the outcomes of the experience, we have considered the results obtained in the activities of each of the phases of the didactic sequence, especially regarding the practical phase and the technological one, as well as the observation of the emotional and motivational manifestations expressed by the students in the classroom diary. The categorization of these results by means of the qualitative software WebQDA allows valuing very positively the experience, both in terms of content learning and motivation generated in the students

Analyzing the comments made in the practical and technological phases, it is possible to appreciate some interesting results:

- $81 \%$ of the students are able to detect curricular elements related to the structure of the city and the role of the wall, both from the visit as from the display with Google Earth.

- $56 \%$ of the students detected different and extra curriculum elements in the last two phases.

- $73 \%$ of the students valued the experience positively.

These results are in line with Boix [7], which support the use of GIS in the study of Social Sciences and with Martínez [12] who positively valued the use of Google Earth in the study of heritage.

To all this, it is necessary to add that this work contributes to generate in the students an overall vision of the city, collaborating with the challenge of sensitizing with the development of sustainable communities and cities. This sensitization of students with the Sustainable Development Goals has acquired great relevance in recent studies [13].

\section{Conclusions}

The experience carried out has fulfilled the learning objectives that were set out and has shown the usefulness of GIS as educational tools, as well as a motivational factor in the study of historical heritage. Despite the limitations of this study, such as the small number of students in the sample or the fact that it was only carried out once, the results support the possibility of it being replicated in subsequent experiences.

\section{References}

1. Estepa, J.; Wamba, A.M.; Jiménez, R. Fundamentos Para Una Enseñanza y Difusión del Patrimonio Desde Una Perspectiva Integradora de las Ciencias Sociales y Experimentales; Diada Editorial: Barcelona, España, 2005.

2. Lleida, M. El patrimonio arquitectónico, una fuente para la enseñanza de la historia y las ciencias sociales. Enseñan. Cienc. Soc. Rev. Investig. 2010, 9, 41-50. 
3. López, J. El papel del patrimonio en los centros educativos: Hacia la socialización patrimonial. Tejuelo Didáct. Leng Lit. Educ. 2014, 19, 76-96.

4. Cuenca, J. El Patrimonio en la Didáctica de las Ciencias Sociales: Análisis de Concepciones, Dificultades y Obstáculos Para su Integración en la Enseñanza Obligatoria; Universidad de Huelva: Huelva, España, 2002.

5. Estepa, J.; Ferreras, M.; López, I.; Morón, H. Análisis del patrimonio presente en los libros de texto: Obstáculos, dificultades y propuestas. Rev. Educ. 2011, 355, 573-589. doi:10-4438/1988-592X-RE-2011-355-037.

6. Gómez, M. La Didáctica de la Geografía y las TIC: Nuevas Metodologías de Enseñanza y Aprendizaje; Universidad de Alicante: Alicante, España, 2016.

7. Boix, G.; Olivella, R. Los Sistemas de Información Geográfica (SIG) aplicados a la educación. El proyecto PESIG (Portal Educativo en SIG). In Actas del VII Congreso Nacional de Didáctica de la Geografía Ciudadanía y Geografía; Universidad de Valencia: Valencia, España, 2007.

8. Corrales, M.; Sánchez, J.; Moreno, J.; Zamora, F. Las motivaciones de los jóvenes para el estudio: Raíces y consecuencias. Cuad. Investig. Juv. 2018, 4, 60-79.

9. Ordine, N. La Utilidad de lo Inútil. Manifiesto; Acantilado: Barcelona, España, 2013.

10. Lázaro, M.L.; González, C. Flipped classroom y cartografía de conflictos en el aprendizaje de la geografía. In Nuevas Perspectivas Conceptuales y Metodológicas para la Educación Geográfica; Martínez, R., Tonda, Y.E., Eds.; AGE: Madrid, España, 2014; pp. 302-318.

11. Salmerón, C. Desarrollo de la Competencia Social y Ciudadana a Través del Aprendizaje Cooperativo; Universidad de Granada: Granada, España, 2010.

12. Martínez, C.; Hernández, M. El uso de Google EarthTM como recurso didáctico en cultura clásica de secundaria para reforzar el aprendizaje del patrimonio arquitectónico romano. Enseñ. Cienc. Soc. Rev. Investig. 2018, 17, 73-85.

13. Zamora-Polo, F.; Sánchez-Martín, J.; Corrales-Serrano, M.; Espejo-Antúnez, L. What Do University Students Know about Sustainable Development Goals? A Realistic Approach to the Reception of this UN Program Amongst the Youth Population. Sustainability 2019, 11, 3533.

(C) 2019 by the authors. Licensee MDPI, Basel, Switzerland. This article is an open access article distributed under the terms and conditions of the Creative Commons Attribution (CC BY) license (http://creativecommons.org/licenses/by/4.0/). 